\title{
Changes in Disease Epidemiology Due to FDA Warning on E-Cigarettes
}

\author{
Abdul Abdussalam* \\ College of Business Administration, University of Nebraska-Omaha, USA
}

Submission: September13, 2018; Published: October 03, 2018

*Corresponding author: Abdul Abdussalam, College of Business Administration, University of Nebraska-Omaha, 7710 Mercy, Road Suite 402, Omaha, NE 68124,USA, Tel: 402-717-9800; Fax: 402-717-6068; Email:aab47629@creighton.edu

\begin{abstract}
The FDA released a statement on September 12, 2018, detailing a push to regulate the e-cigarette industry.This push includes more oversight and aims to regulate e-cigarettes like traditional nicotine products.The alarming trend in the United States is, although nicotine use has decreased over time, the advent of e-cigarettes has led a rise in nicotine consumption among young people.The FDA now takes aim at this issue, and the first step is the statement they released targeting this industry.Though the long-term effects of e-cigarette use are not clear, what are clear are the negative effects of nicotine consumption.It is crucial for us to be vigilant, especially when concerning young people, about limiting harmful effects from e-cigarette use.
\end{abstract}

Keywords: Smoking cessation; E-cigarettes; Nicotine

\section{Opinion}

The path towards smoking cessation in the United States has been a difficult road.Ever since studies first appeared discussing the harmful effects of nicotine on the human body, there has been difficulty in the campaign towards ensuring that people quit smoking, as well as dealing with the short term and longterm repercussions of nicotine use.Through long term sustained efforts, cigarette use in society and their consequences have been on the decline[1].But in recent years however there has been a new wrinkle in the fight against the effects of nicotine use, the emergence of the e-cigarette.That is the moniker for an electronic device that can be used to mimic the smoking of regular cigarettes.Since e-cigarettes have not been around for the length of time that the tobacco industry has existed, there have not been nearly as many studies conducted regarding the safety of these products.

What is most concerning about these new products, confirmed in the statement released by the Food and Drug Administration on September 12, 2018, is the popularity with a younger demographic[2].To that end, the FDA is attempting to take clear action to prevent addictions by teens and other young people.There are several steps that must be taken, which will involve four different parts.To a degree, this all relates to compliance with the policy that is currently in place.First, there will need to be an effort to put in to place a more comprehensive policy for enforcement of the e-cigarette marketplace.Second, the FDA is also initiating additional mechanisms for rooting out the potential sales of these products in ways that are prohibited, especially to minors.The third part of the FDA statement goes along well with this, with additional supervision of digital marketplaces.The final step involves new products that are potentially outside the purview of FDA authority currently. Products created and put on the market after August 8, 2016 fall in a loophole[3].These products have not been subject to the FDA compliance policy.As a result, there has been no pre-market review and there is less oversight in this crucial area.

What are potential changes when it comes to the popularity of e-cigarettes and how that affects population health in the United States?This statement and policy from the FDA may portend a shift away from e-cigarettes and toward traditional cigarettes for some populations. The harmful effects of traditional nicotine delivery mechanisms are well established[4].But what are not as clear are the medical risks for other methods of nicotine, and it could take time before we see any long-term data.What is known about e-cigarettes is the danger that having nicotine in them can cause.The statement from the FDA reiterates the importance for all actors in healthcare to recognize the potential side effects of nicotine in e-cigarettes and the demographics that are at risk.

\section{References}

1. https://www.cdc.gov/tobacco/index.htm 
2. Scott Gottlieb MD (2018) Statement from FDA Commissioner on New Steps to Address Epidemic of Youth e-Cigarette Use. U S Food and Drug Administration.

3. FDA (2016) Deeming Tobacco Products to Be Subject to the Federal Food, Drug, and Cosmetic Act, as Amended by the Family Smoking
Prevention and Tobacco Control Act; Restrictions on the Sale and Distribution of Tobacco Products and Required Warning Statements for Tobacco Products. Federal Register 81(90): 28973-9106.

4. Health Risks of Smoking Tobacco. American Cancer Society, USA.

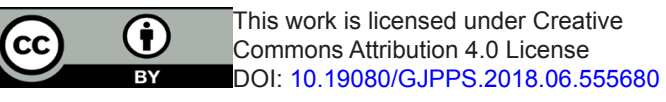

\section{Your next submission with Juniper Publishers will reach you the below assets}

- Quality Editorial service

- Swift Peer Review

- Reprints availability

- E-prints Service

- Manuscript Podcast for convenient understanding

- Global attainment for your research

- Manuscript accessibility in different formats ( Pdf, E-pub, Full Text, Audio)

- Unceasing customer service

Track the below URL for one-step submission https://juniperpublishers.com/online-submission.php 